\title{
Beyond insulin: rethinking cellular metabolism
}

\author{
Craig B Thompson
}

From Metabolism, diet and disease

Washington, DC, USA. 29-31 May 2012

The latest cancer therapeutics are almost all inhibitors of oncogenes or their downstream mediators. With the exception of imatinib, most such drugs have been disappointing in the clinic. In contrast, existing successful cancer drugs have a therapeutic index because they render the consequences of oncogene activation selectively toxic to the cancer cell. A renewed focus on this type of approach appears warranted and should be considered.

Submit your next manuscript to BioMed Central and take full advantage of:

- Convenient online submission

- Thorough peer review

- No space constraints or color figure charges

- Immediate publication on acceptance

- Inclusion in PubMed, CAS, Scopus and Google Scholar

- Research which is freely available for redistribution 